\title{
DAMPAK BUDAYA ORGANISASI, KOMITMEN ORGANISASI DAN DISIPLIN KERJA TERHADAP KINERJA KARYAWAN DI PELAYANAN INDUSTRI, PERDAGANGAN, KOPERASI, USAHA KECIL, MENENGAH DAN TENAGA KERJA (PERINDAKOP) PROVINSI PAPUA
}

\author{
Abiya Pigai ${ }^{1}$, Abdul Rasyid ${ }^{2}$, Saling ${ }^{3}$, \\ 1,2,3Program Studi Manajemen, Fakultas Ekonomi dan Bisnis, Universitas Yapis Papua \\ Jalan Sam Ratulangi No.11, Jayapura, 99113, Indonesia \\ e-mail: abiyapigai123@gmail.com \\ abdullrasyid66@uniyap.ac.id \\ salim.pungker@gmail.com
}

\begin{abstract}
Abstrak
Tinjauan ini mengkaji dampak budaya hierarkis, tanggung jawab berwibawa dan disiplin kerja terhadap presentasi perwakilan di Dinas Perindustrian, Perdagangan, Koperasi, Usaha Kecil Menengah dan Tenaga Kerja (Perindakop) Provinsi Papua. pengujian dilakukan pada sampel 82 responden. Teknik contoh yang digunakan adalah contoh mutlak/contoh terendam. bermacam-macam informasi diselesaikan dengan tinjauan langsung. Pengujian teori dicoba secara eksperimental dengan memanfaatkan berbagai kekambuhan langsung.

Hasil penelitian menunjukkan bahwa budaya hierarkis mempengaruhi pelaksanaan perwakilan, tanggung jawab otoritatif tidak mempengaruhi pelaksanaan pekerja, disiplin kerja mempengaruhi pelaksanaan pekerja dan budaya hierarkis, tanggung jawab otoritatif dan disiplin kerja secara keseluruhan mempengaruhi pelaksanaan perwakilan di Dinas Perindustrian, Perdagangan, Koperasi, Kecil. Usaha, Menengah dan Tenaga Kerja (PERINDAKOP) Provinsi Papua
\end{abstract}

Kata Kunci: budaya organisasi, komitmen organisasi, disiplin kerja dan kinerja pegawai.

\begin{abstract}
This review inspects the impact of hierarchical culture, authoritative responsibility and work discipline on the exhibition of representatives at the Department of Industry, Trade, Cooperatives, Small and Medium Enterprises and Manpower (Perindakop) Papua Province. testing was completed on an example of 82 respondents. The example strategy utilized is absolute example/soaked example. information assortment is finished by direct overview. Speculation testing is tried experimentally utilizing numerous straight relapse.

The outcomes show that authoritative culture influences representative execution, hierarchical responsibility doesn't influence worker execution, work discipline influences representative execution and authoritative culture, hierarchical responsibility and work discipline at the same time influence representative execution at the Department of Industry, Trade, Cooperatives, Small Business, Medium and Manpower (PERINDAKOP) Papua Province.
\end{abstract}

Keywords: Organizational culture, organizational commitment, work discipline and employee performance.

\section{PENDAHULUAN}

Setiap afiliasi, asosiasi atau asosiasi membutuhkan SDM untuk mencapai tujuannya. Sumber daya yang diandalkan untuk menjadi kualitas, perbaikan, kegiatan, kegiatan dan latihan dalam afiliasi, yayasan atau asosiasi. Sumber daya tersebut adalah sebagai sumber daya standar, sumber daya keuangan, SDM, sumber daya cerdas, dan sumber daya mekanik. Di antara banyak sumber daya ini, yang paling penting adalah SDM. SDM adalah sumber daya yang digunakan untuk merencanakan dan memanfaatkan berbagai sumber daya untuk mencapai tujuan.

Dinas Perindustrian, Perdagangan, Koperasi, Usaha Kecil Menengah, dan Tenaga Kerja (Peridagkop) Provinsi Papua Dari hasil pemeriksaan saya yang berlarut-larut, keberadaan tenaga ahli yang kurang menarik terlihat dari berkendara hingga menjelang malam, misalnya , memanfaatkan istirahat yang memuaskan. delegasi yang tidak memiliki cara bekerja dengan harapan dan keinginan yang tulus, kemauan dan keyakinan yang tidak mampu, ini diakhiri dengan tidak memberikan usaha yang jelas kepada spesialis sehingga bisnis spesialis tidak bagus. Delegasi sebagai SDM adalah aset

Copyright $\odot$ Authors. This is an open access article distributed under the Attribution-

NonCommercial-

ShareAlike 4.0 International (CC BY-NC-SA 4.0), which permits unrestricted use, distribution, and reproduction in any medium, provided the original work is properly cited. 
utama yang diklaim oleh suatu afiliasi, asosiasi atau asosiasi. Sejalan dengan itu, pengorganisasian harus dilakukan secara efektif dan cakap (Suhartini, 2021). Setiap afiliasi/lembaga yang menawarkan bantuan dalam bentuk pekerjaan dan barang harus membidik ide organisasi sehingga semua agen dituntut memiliki kemampuan dalam menyelesaikan komitmen dan komitmen yang telah diberikan kepada mereka. Dalam kondisi ini, sumber daya manusia pemimpin mengambil bagian penting dalam memanfaatkan dan membina sumber daya mereka, sehingga afiliasi dapat menawarkan bantuan yang fenomenal serta permintaan terbuka (masyarakat) yang berkembang. Meski demikian, di sana-sini para petinggi kantor atau perkumpulan membutuhkan

Tujuan dan keinginan yang sah, kesiapan dan keyakinan tidak berjalan, hal ini dibuat dengan tidak idealnya memberikan perintah yang jelas kepada agen dengan maksud kepentingan buruh tidak besar.

Pekerja sebagai SDM merupakan sumber daya utama yang dimiliki oleh suatu perkumpulan, pendirian atau organisasi. Oleh karena itu, administrasi harus dilakukan dengan sukses dan mahir (Suhartini, 2021). Setiap asosiasi/lembaga yang menawarkan jenis bantuan sebagai tenaga kerja dan produk harus fokus pada sifat administrasi sehingga semua perwakilan diperlukan untuk memiliki keterampilan dalam melakukan kewajiban dan kewajiban yang telah dialokasikan kepada mereka. Dalam kondisi seperti ini, aset manusia dewan memainkan peran penting dalam menggunakan dan membina aset yang dimilikinya, sehingga asosiasi dapat menawarkan dukungan yang luar biasa seiring dengan perubahan permintaan secara terbuka (masyarakat). Namun terkadang para pimpinan yayasan atau organisasi kurang teliti dalam menyelesaikan tugasnya sebagai ketua. Terkadang komponen administrasi hanya meminta bawahannya untuk menyelesaikan pekerjaan sesuai waktu yang ditentukan, namun berusaha mengabaikan keseimbangan volume pekerjaan, derajat pedoman pelaksanaan, dan waktu yang telah dialokasikan untuk perwakilan di masing-masing. unit kerja atau eksklusif.

Salah satu variabel yang dapat mempengaruhi pelaksanaan pekerja adalah budaya hierarkis, di mana klarifikasi seperti yang ditunjukkan oleh Robbins (2010: 76) menjelaskan bahwa budaya otoritatif telah diperkenalkan sebagai kualitas, standar, kebiasaan dan metode kerja yang dimiliki oleh individu dari asosiasi. dan mempengaruhi cara mereka bertindak. Dari penilaian ini, sangat menggarisbawahi upaya untuk lebih mengembangkan pelaksanaan yang lebih berkualitas dalam mengurus bisnis sebagai kewajiban dan tanggung jawab. orang-orang yang secara konsisten mematuhi untuk mendapatkan hasil yang sangat menyenangkan. Penegasan ini dapat dikuatkan oleh penelitian Sarfilianty Anggiani, (2021). Hasil penelitian menunjukkan bahwa budaya otoritatif sampai batas tertentu memiliki dampak positif dan besar terhadap eksekusi pekerja di PT. Garuda Indonesia Tbk.

Elemen kedua yang dapat mempengaruhi pelaksanaan pekerja adalah Komitmen Organisasi, yang seperti yang ditunjukkan oleh Robbins dan Hakim (2009) mencatat bahwa hasil pemeriksaan oleh peneliti menunjukkan bahwa tanggung jawab hierarkis memiliki hubungan negatif dengan pembolosan dan pergantian. Penegasan ini dapat dikuatkan oleh penelitian Sarfilianty Anggiani, (2021). Hasil penelitian menunjukkan bahwa tanggung jawab otoritatif sampai taraf tertentu berdampak positif dan kritis terhadap pelaksanaan pekerja di PT. Garuda Indonesia Tbk. Bagaimanapun, konsekuensi dari pemeriksaan oleh Sarfilianty Anggiani, (2021). Berbeda dengan pemeriksaan Syahnur, (2021). Hasil penelitian menunjukkan bahwa budaya otoritatif tidak berdampak pada eksekusi representatif.

Unsur ketiga atau terakhir yang dapat mempengaruhi pelaksanaan pekerja adalah disiplin kerja, yang ditunjukkan oleh Siagian (2010:305) Disiplin kerja adalah kegiatan administrasi untuk mendorong individu yang berwibawa untuk memenuhi kebutuhan pengaturan administrasi yang berbeda. Selain itu, seperti yang ditunjukkan oleh Hasibuan (2011: 193) Disiplin kerja adalah kesadaran dan keinginan individu untuk tunduk pada semua pedoman organisasi dan praktik yang diterima secara material. Hal ini dapat dikuatkan oleh penelitian (2014), bahwa disiplin kerja memiliki dampak positif dan besar terhadap pelaksanaan kerja. Penelitian Agus et al (2016), bahwa disiplin kerja berpengaruh positif dan kritis terhadap pelaksanaan.

Berdasarkan penelitian Safitri (2013), menyatakan bahwa disiplin kerja berdampak positif dan besar terhadap pelaksanaan representatif. Sementara itu, Mahardika dkk (2015), mengungkapkan bahwa disiplin kerja memiliki dampak positif dan besar terhadap pelaksanaan.

Dengan adanya kejelasan gagasan dan faktor-faktor nyata yang terjadi serta akibat-akibat dari penyelidikan observasional di atas, maka tampak adanya kebimbangan dalam hasil eksplorasi. Ini menyiratkan bahwa kebimbangan atau inkonsistensi logis dari hasil pemeriksaan benar-benar 
merupakan lubang eksplorasi. Maka dari inkonsistensi dan realitas logis ini, para ilmuwan perlu melakukan penelitian luar dan dalam tentang "Pengaruh Budaya Organisasi, Komitmen Organisasi dan Disiplin Kerja Terhadap Kinerja Pegawai Dinas Perindustrian, Perdagangan, Koperasi, Usaha Kecil Menengah dan Tenaga Kerja (Perindagkop) Provinsi Papua"

\section{Pengembangan Hipotesis Penelitian}

Dalam tinjauan ini, ilmuwan perlu melihat apakah presentasi tinggi dan rendah adalah variabel yang bergantung pada skor tinggi dan rendah pada faktor bebas yang ditetapkan dalam tinjauan ini, khususnya budaya otoritatif, tanggung jawab hierarkis, dan disiplin kerja. Wahyu dkk. (2006) Hipotesis adalah praduga esensial dari sesuatu yang dipikirkan valid untuk alasan penilaian meskipun kenyataan sebenarnya harus ditunjukkan.

Pengaruh Budaya Organisasi Terhadap Kinerja Karyawan.

Robbins (2010: 76) menjelaskan bahwa budaya otoritatif telah dikembangkan sebagai kualitas, standar, kebiasaan dan metode kerja yang dimiliki oleh individu dari asosiasi dan mempengaruhi cara mereka bertindak. Dari penilaian ini, sangat digaris bawahi

Berusaha dengan cara yang paling mahir untuk bekerja pada pelaksanaan yang lebih baik dalam mengurus bisnis sebagai kewajiban dan kewajiban orang-orang yang secara konsisten mematuhi untuk mendapatkan hasil yang sangat menyenangkan.

Pada dasarnya, semua asosiasi memiliki budaya, namun tidak semua masyarakat hierarkis sama solidnya dalam memengaruhi perilaku dan aktivitas pekerja. Semakin tinggi tingkat pengakuan perwakilan terhadap keyakinan dasar asosiasi dan semakin penting kewajiban mereka terhadap kualitaskualitas ini, semakin membumi budaya otoritatif dan semakin tinggi evaluasi disiplin kerja atau pengawasan pelaksanaan pekerja. Namun budaya yang kokoh juga memiliki kekurangan, khususnya budaya berwibawa yang kuat biasanya akan membuat pekerja tidak berani mencoba cara-cara baru, terutama dalam mengelola keadaan yang berkembang pesat. Untuk situasi ini tidak salah lagi cara hidup yang ditanamkan dalam asosiasi memiliki komitmen kritis terhadap eksekusi pekerja. Ketika perwakilan memahami kualitas yang ada dalam asosiasi mereka, itu akan mempengaruhi kinerja mereka.

Penegasan di atas dapat dikuatkan dengan pemeriksaan Wardhani Hakim, (2019. Hasil penelitian menunjukkan bahwa budaya hierarkis berpengaruh signifikan terhadap eksekusi representatif. Tamaela (2014) menyatakan bahwa budaya organisasi berdampak positif dan signifikan terhadap kinerja karyawan. Konsekuensi dari tinjauan ini sesuai dengan Sarfilianty Anggiani, (2021. Konsekuensi tinjauan menunjukkan bahwa hierarkis) budaya dan tanggung jawab otoritatif secara bersamaan berpengaruh signifikan terhadap pelaksanaan perwakilan di PT Garuda Indonesia Tbk. Namun, konsekuensi dari tinjauan ini bertentangan dengan penelitian Syahnur, (2021) Hasil penelitian menunjukkan bahwa budaya hierarkis tidak berdampak pada pelaksanaan perwakilan.

\section{$\mathrm{H}_{1}$ : Budaya Organisasi Mempengaruhi Kinerja KaryawanPengaruh komitmen organisasi Dengan kinerja pegawai}

Perwakilan yang fokus pada perkumpulan mungkin dapat lebih mengembangkan eksekusi baik secara mandiri, dalam perkumpulan maupun dalam perkumpulan. Perwakilan yang memiliki tanggung jawab otoritatif tinggi akan memberikan tenaga yang paling ekstrim dengan sengaja untuk kemajuan asosiasi. Mereka akan berusaha untuk mencapai tujuan otoritatif dan mengikuti kualitas hierarkis. Terlebih lagi, mereka akan tertarik dan terlibat secara efektif dengan mendorong asosiasi. Pekerja yang memiliki tanggung jawab yang tinggi akan dapat diandalkan dengan bersedia memberikan semua kemampuannya karena mereka percaya bahwa mereka memiliki asosiasi. Perasaan yang kokoh akan tempat akan menyebabkan pekerja merasa berharga dan menyenangkan dalam pergaulan (Yuwono: 2005). Mayer dan Allen. (1990) juga menjelaskan bahwa pekerja yang memiliki tanggung jawab pengaturan tinggi tetap menjadi individu dari asosiasi karena mereka perlu melakukannya. tanggung jawab ini tergantung pada standar dalam diri pekerja, yang berisi keyakinan individu tentang kewajiban terkait dengan asosiasi. Dia merasa bahwa dia perlu bertahan karena keandalan. Jalan menuju tanggung jawab ini adalah komitmen untuk tetap berada dalam pergaulan (seharusnya). Tanggung jawab semacam ini lebih karena kebajikan yang sebenarnya dimiliki perwakilan.

Kerinduan untuk keluar dari perkumpulan sebagian besar didahului oleh tujuan seorang wakil yang antara lain dipicu oleh kekecewaan pekerja terhadap pekerjaan dan kurangnya kewajiban pekerja terhadap perkumpulan. Robbins dan Judge (2009) mencatat bahwa konsekuensi eksplorasi oleh peneliti menunjukkan bahwa tanggung jawab hierarkis memiliki hubungan negatif dengan pembolosan dan 
pergantian.

Tampaknya tanggung jawab emosional memiliki hubungan yang lebih dekat dengan hasil otoritatif seperti eksekusi dan pergantian perwakilan daripada dua komponen tanggung jawab lainnya. Analis seperti Sarmina Samad (2006) mengklarifikasi bahwa tanggung jawab hierarkis yang bergantung pada tiga elemen tanggung jawab memiliki konsekuensi kritis dan merugikan pada keinginan untuk pindah. Demikian pula dengan penelitian yang diarahkan oleh Abdul Rohman (2009) yang menunjukkan bahwa penuh rasa tanggung jawab dan tanggung jawab berkelanjutan.

Penegasan di atas dapat dikuatkan oleh penjelajahan Kharismasyah, (2019). Hasil penelitian menunjukkan bahwa tanggung jawab otoritatif berpengaruh signifikan terhadap pelaksanaan pekerja.

\section{$\mathrm{H}_{2}$ : Tanggung jawab organisasi mempengaruhi pelaksanaan perwakilan} Pengaruh Disiplin Kerja Dengan Kinerja Karyawan

Hubungan positif antara disiplin kerja dan pelaksanaan telah dibuktikan oleh beberapa penelitian oleh Saputra Mutmainnah Herlie, (2010) Disiplin adalah pekerjaan utama HRM dan cara untuk mencapai tujuan mengingat fakta bahwa tanpa disiplin yang tinggi sulit untuk mencapai sebagian besar pekerjaan. tujuan ekstrim. Disiplin adalah kerinduan dan perhatian untuk mematuhi pedoman hierarkis dan praktik normal.

Dalam penelitian Ova Nuracto Sofiati, (2015) disiplin kerja berpengaruh terhadap pelaksanaan pekerja, baik secara preventif, restoratif maupun moderat. Disiplin kerja yang representatif sangat penting untuk faktor presentasi. bahwa salah satu penentu kecukupan pelaksanaan adalah disiplin kerja. persiapan, dan pendekatan otoritatif). Juga, variabel ekologi otoritatif.

Pernyataan di atas dapat dikuatkan oleh penelitian Rizka Afista, (2018). ada dampak yang tidak lengkap dari faktor disiplin kerja pada pelaksanaan perwakilan.

\section{$\mathrm{H}_{3}$ : Disiplin Kerja Mempengaruhi Kinerja Karyawan \\ Pengaruh Budaya Organisasi Secara Simultan, Komitmen Organisasi dan Disiplin Kerja Terhadap Kinerja Karyawan}

Budaya organisasi yang mengisi bisnis, pertukaran, koperasi, usaha kecil, menengah dan tempat kerja (Perindakop) Provinsi Papua harus memiliki pilihan untuk memperluas tanggung jawab dan disiplin kerja para wakilnya sehingga dapat menciptakan pelaksanaan yang menyenangkan dan membujuk pekerjaan. Meskipun demikian, jenis tanggung jawab yang tampaknya diandalkan tidak hanya berupa pengabdian yang terpendam, tetapi juga mencakup hubungan yang dinamis dengan asosiasi kerja yang bertujuan memberikan segala upaya untuk pencapaian yang berwibawa, tekanan dan penjaga pintu (dalam Sopiah, 2008). Orang-orang yang lebih berdedikasi untuk asosiasi mereka akan lebih siap untuk mengajukan upaya untuk pencapaian asosiasi. Upaya bersama antara budaya otoritatif, tanggung jawab hierarkis dan disiplin kerja diandalkan untuk menjadi satu kesatuan yang kuat sehingga dapat memberikan eksekusi yang hebat dan sesuai pencapaian tujuan.

Pernyataan di atas dapat dikuatkan oleh penelitian Rizka Afista, (2018). ada dampak yang tidak lengkap dari faktor budaya hierarkis, disiplin kerja dan tanggung jawab otoritatif pada saat yang sama pada pelaksanaan perwakilan.

\section{$\mathrm{H}_{4}$ : Budaya Organisasi, Komitmen Organisasi dan Disiplin Kerja Secara Bersamaan Mempengaruhi Kinerja Karyawan \\ METODE}

Jenis Dan Rancangan Penelitian

Pemeriksaan semacam ini adalah eksplorasi kausal dengan strategi gambaran umum yang menyatakan bahwa rencana kausal itu berharga bel yang mempengaruhi faktor-faktor yang berbeda, dan juga berharga dalam penelitian pengujian, di mana faktor bebas diperlukan dengan cara yang terkontrol oleh analis untuk melihat pengaruhnya terhadap variabel terikat secara langsung. strategi review adalah prosedur eksplorasi di mana data/informasi dikumpulkan dengan menggunakan polling. Review adalah strategi pengumpulan informasi yang penting dengan memberikan pertanyaan pada reaksi individu.

\section{Objek Penelitian}

Obyek eksplorasi ini diselesaikan di Dinas Perindustrian, Perdagangan, Koperasi, Usaha Kecil Menengah dan Tenaga Kerja (PERINDAKOP) Provinsi Papua yang beralamat di Jln. Percetakan Negara (7,44km) Kota Jayapura, Papua 99223. Waktu ujian dimulai Juli 2021.

Populasi 
Populasi adalah daerah spekulasi yang terdiri dari subyek atau barang dengan ciri dan sifat tertentu yang didikte oleh eksplorasi untuk dikonsentrasikan dan kemudian dilakukan penentuan, sedangkan penduduk yang ditinjau adalah 100 tenaga kerja yang diperoleh dari segmen kepegawaian Departemen Perindustrian., Perdagangan, Koperasi, Usaha Kecil, Menengah dan Tenaga Kerja (PERINDAKOP) Provinsi Papua.

\section{Sampel}

Contoh sangat penting untuk jumlah dan atribut yang dipindahkan oleh penduduk. Jika populasinya besar, dan tidak mungkin bagi ilmuwan untuk berkonsentrasi pada keseluruhan populasi saat ini, spesialis dapat menggunakan tes yang diambil dari populasi. Arikunto (2006). menyatakan bahwa dengan asumsi subjek besar, cenderung diambil antara 10\%-15\% atau 20\%-25\% atau lebih. Terlebih lagi, subjeknya di bawah 100 individu, lebih pintar untuk mengambil masing-masing dari mereka. Mengingat penilaian di atas, prosedur pengujian yang digunakan dalam tinjauan ini adalah contoh lengkap/contoh rendam. Jadi contoh yang diambil adalah semua pekerja menjumlahkan hingga 100 perwakilan.

\section{Teknik untuk mengumpulkan informasi}

Bermacam-macam informasi sangat penting karena berkaitan dengan aksesibilitas informasi yang diharapkan dapat menjawab permasalahan dalam penelitian sehingga tujuan yang diambil tepat. Oleh karena itu, penelitian tentang teknik pemilihan informasi harus dilakukan dengan cara yang sesuai. Dalam tinjauan ini berbagai informasi yang digunakan oleh para ilmuwan adalah:

\section{Metode Pengangkatan (jajak pendapat)}

Jajak pendapat adalah berbagai pertanyaan tersusun yang digunakan untuk mendapatkan data dan responden sejauh laporan tentang diri mereka sendiri atau hal-hal yang mereka ketahui (Arikunto, 1998:139). Teknik ini digunakan untuk mengembalikan informasi tentang budaya berwibawa, tanggung jawab hierarkis dan disiplin kerja serta dampaknya terhadap pelaksanaan perwakilan pada survei Dinas Perindustrian, Perdagangan, Koperasi, Usaha Kecil Menengah dan Tenaga Kerja (Perindakop) Provinsi Papua untuk mengukur budaya berwibawa, berwibawa tanggung jawab dan disiplin. pekerjaan dan pelaksanaan perwakilan diberikan kepada pekerja itu sendiri. Untuk menemukan perulangan peruntukan setiap faktor yang mengumpulkan informasi dengan menggunakan survei (lift), setiap tanda dari informasi yang dikumpulkan pertama-tama dicirikan dan diberi skor atau nilai, khususnya:

Skor 1 jika jawaban responden sangat aneh (STS)

Skor 2 dengan asumsi jawaban responden tidak setuju (TS)

Skor 3 dengan asumsi jawaban responden tidak setuju (KS)

Skor 4 dengan asumsi jawaban responden setuju (S)

\section{Metode Analisis Data}

Metode analisis data adalah mencari informasi tentang hal-hal atau varietas seperti catatan, catatan buku, makalah, majalah, ukiran pertemuan, rencana, dll (Arikunto, 1998: 234) strategi ini digunakan sebagai pelengkap untuk mendapatkan informasi sebagai bahan data yang digunakan dalam riset. Ini menggabungkan desain otoritatif.

\section{Pengujian Instrumen .}

Instrumen yang layak harus memenuhi dua prasyarat penting, yaitu legitimasi khusus dan kualitas yang tak tergoyahkan. Untuk menentukan keabsahan dan keandalan informasi (skor) yang diperoleh untuk setiap hal, tes mendasar digantung pada jajak pendapat kepada responden, kemudian, pada saat itu, informasi (skor) yang diperoleh diuji keabsahan dan kualitasnya.

\section{Uji Validitas}

Validasi adalah tindakan yang menunjukkan derajat legitimasi dan tambahan legitimasi suatu instrumen (Arikunto, 1998:60). Instrumen tersebut dianggap substansial dengan asumsi dapat mengukur apa yang diinginkan, jika dapat mengungkap informasi faktor-faktor yang terkonsentrasi sesuai. Dalam audit ini, keaslian yang digunakan adalah uji Pearson Correlation. Pengujian keabsahan data dapat diperoleh pasangan skor yang didapat pada setiap pertanyaan dengan skor langsung dari setiap pergantian peristiwa. Jika koefisien got Pearson memiliki signifikansi di bawah tingkat 0,05 , itu berarti bahwa data yang diperoleh murah hati.

\section{Uji Reabilitas}

Tes berikut selesai adalah tes ketergantungan. Uji ketergantungan ini digunakan menentukan konsistensi tanggapan responden terhadap pertanyaan yang diajukan. Uji ketergantungan ini diselesaikan dengan menggunakan Cronbach' Alpha. Menurut Sugiyono (2009:86) uji ketergantungan 
dapat dilakukan secara bersama-sama pada semua pertanyaan untuk lebih dari satu variabel, namun pada kenyataannya uji kualitas tetap dilakukan pada setiap faktor pada lembar kerja alternatif dengan tujuan agar cenderung terlihat. variabel mana yang berkembang tidak solid. . Instrumen tersebut dikatakan dapat diandalkan jika nilai Cronbach Alpha yang ditentukan lebih tinggi daripada Cronbach Alpha jika item yang Dihapus, polling diumumkan secara solid.

\section{Uji Asumsi Klasik}

Sebuah model perulangan langsung yang berbeda dapat disebut model yang tepat jika memenuhi gagasan keteraturan informasi dan bebas dari asumsi gaya lama tentang keteraturan, multikolinearitas, autokorelasi, dan heteroskedastisitas. Klarifikasi dari setiap uji kecurigaan gaya lama (Ghosali, 2006 adalah sebagai berikut:

\section{Uji Normalitas}

Uji konsistensi ini diandalkan untuk memilih penyebaran data pada elemen-elemen yang akan digunakan dalam audit. Data yang bagus dan layak digunakan dalam penelitian adalah data yang biasa disebarluaskan. Dalam survei ini, uji mandat dibantu melalui Uji Probabilitas Normal (P-P Plot) dan uji Kolmogorov-Smirnov. Dalam pengujian menggunakan prosedur Normality Probality Plot (PP Plot), sebuah variabel dianggap biasa dengan anggapan gambar alat angkut dengan titik fokus data tersebar di sekitar garis miring, dan pengangkutan produk penting dengan cara berikut garis miring (Imam Ghozali, 2011:63) dan dalam uji Kolmogorov Smirnov suatu variabel dianggap tipikal jika nilai signifikansinya > 0,05 (95\% kepastian). Tes ini selesai menggunakan pemrograman IBM SPSS Statistics

\section{Uji Heteroskedastisitas}

Uji heteroskedastisitas berarti menguji apakah pada model backslide terdapat ketidaksesuaian yang kontras dengan residual perseptual lainnya. Mengharapkan kontras yang tersisa dalam wawasan yang berbeda tetap ada, itu disebut homoskedastisitas dan dengan asumsi berbeda itu disebut heteroskedastisitas. Model backslide yang sesuai adalah homoskedastisitas (Imam Ghozali, 2011:139) atau tidak terjadi heteroskedastisitas. Pengungkapan ada tidaknya heteroskedastisitas dapat dilihat dari ada tidaknya model eksplisit pada grafik scatterplot. Menerima adanya model yang jelas, misalnya sentuhan yang membentuk model konvensional tertentu (bergelombang, diperkuat, kemudian, dibatasi) maka menunjukkan telah terjadi heteroskedastisitas. Jika tidak ada model yang pasti, dan pusat tersebar di atas dan di bawah angka 0 pada titik pusat Y, maka tidak terjadi heteroskedastisitas (Imam Ghozali, 2011:139). Tes ini selesai menggunakan pemrograman IBM SPSS Statistics 21

\section{Uji Multikolinearitas}

Uji multikolinearitas mengandung makna pengujian apakah dalam model backslide terdapat hubungan antar variabel otonom (faktor bebas), (Ghozali, 2011:105). Model backslide yang baik seharusnya tidak memiliki hubungan antara elemen otonom.

Untuk mengetahui ada atau tidaknya multikolinearitas pada model backslide, secara umum akan diatasi dengan menganalisis nilai Tolerance dan VIF (Variance Inflation Factor). Kedua ukuran ini menunjukkan variabel otonom mana yang dijelaskan oleh faktor bebas lainnya. Oposisi menilai faktor-faktor bebas terpilih yang tidak dijelaskan oleh variabel bebas lainnya. Dengan demikian, biaya obstruksi rendah hampir sama tuanya dengan biaya VIF Uji tinggi (dengan penjelasan bahwa VIF $=1 /$ kekuatan). Nilai yang biasanya digunakan untuk menunjukkan adanya multikolinearitas adalah nilai Tolerance sebesar 0,10 atau setua nilai VIF sebesar 10. Setiap peneliti harus menentukan levelnya. Kemudian, kehadiran antara variabel independen dalam sebuah model akan mendorong hubungan yang sangat besar antara satu komponen bebas dan lainnya. (Nugroho, 2005: 58). Pengujian ini diselesaikan dengan menggunakan Program SPSS 21

Berdasarkan gambaran di atas, tinjauan ini berencana untuk memutuskan dampak faktor bebas, khususnya Budaya Organisasi (X1), Komitmen Organisasi (X2) dan disiplin kerja (X3) terhadap pelaksanaan pekerja (Y). Jenis kondisi kekambuhan langsung yang berbeda adalah sebagai berikut:

\section{Uji hipotesis}

Pengujian teori dilakukan dengan pengandaian yang menyertai Pengujian Hipotesis:

\section{Uji Teori (Uji t)}

Pemeriksa Teori 1 melihat apakah Budaya Organisasi, Komitmen Organisasi dan Disiplin Kerja secara tunggal atau agak signifikan mempengaruhi Kinerja Pegawai pada Dinas Perindustrian, Perdagangan, Koperasi, Usaha Kecil Menengah dan Tenaga Kerja (PERINDAKOP) Provinsi Papua. Pengujian ini diselesaikan dengan terlebih dahulu mengikuti koefisien b1 terbesar, kemudian pada saat 
itu, sekitar kemudian, menguji signifikansinya dengan uji tidak memadai (uji t), dengan menggunakan kondisi, Sumodiningrat, (1999) sebagai berikut:

$\mathrm{t}=1: \operatorname{Se}(\beta \mathrm{i})$

Di mana :

$\mathrm{t}=$ Nilai $\mathrm{t}$ hitung

$\mathrm{I}=$ Koefisien Parameter

$\operatorname{Se}(\beta i)=$ Batas koefisien kesalahan standar

Seluk-beluk hipotesis yang diungkap oleh:

Ho : bi $=\mathrm{O}$

$\mathrm{Ha}$ : bi O

Dengan asumsi hasil perhitungan menunjukkan:

Karena uji $\mathrm{t}>\mathrm{t}$ tabel dan Probabilitas $<0,05$ maka Ho ditolak (Ha dipersepsikan) yang menunjukkan bahwa unsur budaya definitif, kewajiban progresif dan disiplin kerja sedikit banyak atau semata-mata mempengaruhi perhitungan pelaksanaan tenaga kerja Dinas Perindustrian, Perdagangan, Koperasi, Usaha Kecil, Menengah dan Tenaga Kerja (PERINDAKOP) Provinsi Papua pada tingkat kepastian $95 \%$.

\section{Uji Konkuren (Uji f)}

Uji spekulasi lain yang digunakan adalah uji $\mathrm{F}$ dengan derajat besar 5\%. Langkah-langkah tes adalah; dengan asumsi $\mathrm{F}$ hitung $>\mathrm{F}$ tabel maka Ho ditolak dan Ha diakui yang menyiratkan bahwa ada pengaruh budaya otoritatif, tanggung jawab hierarkis dan disiplin kerja terhadap pelaksanaan pekerja. Ghozali, (2005).

\section{Uji Koefisien Determinasi $\left(\mathbf{R}^{2}\right)$}

Koefisien konfirmasi $\left(\mathrm{R}^{2}\right)$ pada dasarnya mengukur seberapa jauh kemampuan model dalam menjelaskan keragaman variabel terikat. Nilai kecil dari R2 menyimpulkan bahwa batas faktor bebas untuk menjelaskan variasi variabel terikat sangat terbatas. Nilai-nilai yang mendekati salah satu strategi Untuk mengetahui ada tidaknya multikolinearitas pada model backslide, cenderung diatasi dengan melihat nilai Tolerance dan VIF (Variance Inflation Factor). Kedua ukuran ini menunjukkan elemen bebas mana yang dijelaskan oleh komponen independen lainnya. Obstruksi menilai faktor-faktor bebas terpilih yang tidak dijelaskan oleh variabel bebas lainnya. Sepanjang garis ini, biaya keserbagunaan rendah hampir sama tuanya dengan biaya VIF tinggi (dengan penjelasan bahwa VIF $=1$ /oposisi). Nilai yang biasanya digunakan untuk menunjukkan adanya multikolinearitas adalah nilai Tolerance sebesar 0,10 atau setua nilai VIF 10. Setiap penguji harus menentukan levelnya. Kemudian, pada saat itu, pada saat itu, kemiripan antara faktor-faktor bebas dalam sebuah model akan mendorong hubungan yang sangat mencengangkan antara satu variabel independen dan elemen otonom lainnya. (Nugroho, 2005: 58). Pengujian ini dilakukan dengan memanfaatkan SPSS 21 . program

Faktor bebas memberikan hampir semua informasi yang diharapkan untuk meramalkan keragaman variabel terikat Ghozali, (2007). Jika ragu, koefisien afirmasi untuk data cross-sectional lebih rendah karena variasi yang sangat besar antara setiap wawasan, sedangkan untuk data deret waktu, biasanya memiliki koefisien konfirmasi yang tinggi.

Kerugian mendasar dari penggunaan koefisien kepastian adalah kecenderungan terhadap kuantitas faktor bebas yang dikaitkan dengan model pada kuantitas elemen independen, maka, R2 harus maju, apakah variabel pada dasarnya mempengaruhi variabel otonom atau tidak.

\section{HASIL DAN PEMBAHASAN \\ Pengaruh Budaya Organisasi Terhadap Kinerja.}

Dilihat dari tabel 4.15, nilai kepentingan adalah 0,032 (kemungkinan $<0,005$ ) dengan thitung 2,185 sedangkan t-tabel adalah 1,675 sehingga thitung < ttabel $(2,185<1,675)$ yang berarti bahwa teori utama diakui. Sangat mungkin diduga bahwa spekulasi utama adalah bahwa Budaya Organisasi mempengaruhi pameran perwakilan di Dinas Perindustrian, Perdagangan, Koperasi, Usaha Kecil Menengah dan Tenaga Kerja (PERINDAKOP) Provinsi Papua. Konsekuensi dari pengujian spekulasi utama menunjukkan bahwa Budaya Organisasi mempengaruhi eksekusi pekerja. Sangat baik dapat disimpulkan bahwa Budaya Organisasi dapat lebih mengembangkan eksekusi pekerja. Ini menyiratkan

Dengan semakin suksesnya budaya dalam suatu perkumpulan, maka pekerjaan yang dilakukan juga akan mempengaruhi perluasan energi dalam mengembangkan pelaksanaan representatif lebih lanjut. 
Sementara terjemahan di lapangan menyiratkan bahwa budaya hierarkis di Dinas Perindustrian, Perdagangan, Koperasi, Usaha Kecil Menengah dan Tenaga Kerja (PERINDAKOP) Provinsi Papua. berjalan cukup baik sehingga mempengaruhi pelaksanaan perwakilan. Dengan budaya hierarkis yang layak, maka akan menjunjung tinggi pelaksanaan kerja perwakilan.

Penegasan di atas dapat dikuatkan oleh eksplorasi Wardhani Hakim, (2019. Hasil penelitian menunjukkan bahwa budaya otoritatif berpengaruh signifikan terhadap eksekusi pekerja. Konsekuensi dari tinjauan ini sesuai dengan Sarfilianty Anggiani, (2021. Efek samping dari tinjauan menunjukkan bahwa hierarki Budaya berpengaruh secara signifikan terhadap eksekusi pekerja di PT Garuda Indonesia Tbk. Namun, konsekuensi dari tinjauan ini bertentangan dengan pengujian Syahnur (2021) Hasil penelitian menunjukkan bahwa budaya otoritatif tidak berpengaruh terhadap eksekusi pekerja. Pengaruh Komitmen Organisasi Terhadap Kinerja.

Berdasarkan tabel 4.15, nilai kepentingan adalah 0,066 (kemungkinan $>0,005$ ) dengan thitung sebesar - 1,861 sedangkan $t$ tabel sebesar 1,675 sehingga thitung > ttabel $(-1,861>1,675)$ yang berarti bahwa spekulasi selanjutnya ditolak. Dapat diduga bahwa teori selanjutnya adalah Komitmen Organisasi tidak berdampak pada pelaksanaan perwakilan di Dinas Perindustrian, Perdagangan, Koperasi, Usaha Kecil, Menengah dan Tenaga Kerja (PERINDAKOP) Provinsi Papua.

Efek samping dari pengujian spekulasi berikutnya menunjukkan bahwa budaya kerja tidak berdampak pada eksekusi pekerja. Dapat disimpulkan bahwa Komitmen Organisasi tidak dapat mendukung pelaksanaan pekerja. Artinya dengan menurunnya Organizational Commitment maka akan mempengaruhi pelaksanaan representatif begitu juga sebaliknya.

Sementara terjemahan di lapangan menyiratkan bahwa tanggung jawab otoritatif di Dinas Perindustrian, Perdagangan, Koperasi, Usaha Kecil, Menengah dan Tenaga Kerja (PERINDAKOP) Provinsi Papua sangat rendah sehingga mempengaruhi pelaksanaan perwakilan. Dengan berkurangnya tanggung jawab hierarkis, pelaksanaan perwakilan akan berkurang.

Mayer dan Allen. (1990) juga menjelaskan bahwa perwakilan yang memiliki tanggung jawab standardisasi tinggi tetap menjadi individu dari asosiasi karena mereka perlu melakukan hal tersebut.

Pernyataan di atas dapat dikuatkan dengan pemeriksaan Kharismasyah, (2019). Hasil penelitian menunjukkan bahwa tanggung jawab hierarkis secara signifikan mempengaruhi pelaksanaan perwakilan.

\section{Pengaruh Disiplin Kerja Dengan Kinerja Karyawan}

Berdasarkan tabel 4.15, nilai kepentingan adalah 0,000 (kemungkinan $<0,005$ ) dengan thitung 11,299 sedangkan t-tabel adalah 1,675 sehingga thitung > ttabel $(11,299>1,675)$ yang berarti bahwa spekulasi ketiga diakui. Dapat disimpulkan bahwa spekulasi ketiga, khususnya Disiplin Kerja, mempengaruhi eksekusi pekerja di Dinas Perindustrian, Perdagangan, Koperasi, Usaha Kecil, Menengah, dan Tenaga Kerja (PERINDAKOP) Provinsi Papua.

Konsekuensi dari pengujian teori selanjutnya menunjukkan bahwa disiplin kerja mempengaruhi pelaksanaan pekerja. Hal ini cenderung beralasan bahwa disiplin kerja yang baik dapat menegakkan eksekusi pekerja. Artinya dengan meluasnya kedisiplinan pekerja dalam bekerja maka akan berdampak pada perluasan pelaksanaan perwakilan begitu pula sebaliknya.

Hubungan positif antara disiplin kerja dan pelaksanaan telah ditunjukkan dengan adanya: beberapa penelitian oleh Saputra Mutmainnah Herlie, (2010) Disiplin adalah pekerjaan utama HRM dan cara untuk mencapai tujuan dengan alasan bahwa tanpa disiplin yang tinggi sulit untuk mencapai tujuan yang paling ekstrim. Disiplin adalah keinginan dan perhatian untuk tunduk pada pedoman otoritatif dan praktik normal.

Pernyataan di atas dapat dikuatkan oleh penelitian Rizka Afista, (2018). ada dampak yang tidak lengkap dari faktor disiplin kerja pada pelaksanaan perwakilan.

Pengaruh Budaya Organisasi, Komitmen Organisasi dan Disiplin Kerja Secara Bersamaan Terhadap Kinerja.

Spekulasi terakhir dalam ulasan ini mengungkapkan bahwa "Budaya Hirarki, Komitmen Organisasi dan Disiplin Kerja Secara Bersamaan Mempengaruhi Kinerja". Berdasarkan hasil pemeriksaan pada Tabel 4.15 dapat dilihat dengan baik bahwa nilai $\mathrm{F}$ yang ditentukan adalah 51,258 yang lebih menonjol dari $\mathrm{F}$ tabel yang hanya 2,557 dengan arti 0,000 yang juga < dari nilai $\mathrm{p} 0,005$ sehingga $\mathrm{H} 4$ diakui menyiratkan bahwa Budaya Organisasi, Komitmen Organisasi dan Disiplin Kerja Secara Bersamaan Mempengaruhi Kinerja.

Pernyataan di atas dapat dikuatkan oleh penelitian Rizka Afista, (2018). ada dampak setengah jalan dari 
faktor budaya hierarkis, disiplin kerja dan tanggung jawab otoritatif sementara pada pelaksanaan pekerja.

\section{PENUTUP}

\section{Kesimpulan}

Dilihat dari percakapan hasil pemeriksaan, tujuan yang dapat ditempuh melalui eksplorasi ini adalah sebagai berikut;

Budaya hierarkis mempengaruhi pameran perwakilan di Dinas Perindustrian, Perdagangan, Koperasi, Usaha Kecil Menengah dan Tenaga Kerja (PERINDAKOP) Provinsi Papua.

Tanggung jawab kewenangan tidak mempengaruhi keterwakilan perwakilan di Dinas Perindustrian, Perdagangan, Koperasi, Usaha Kecil Menengah dan Tenaga Kerja (PERINDAKOP) Provinsi Papua.

Disiplin kerja berpengaruh terhadap presentasi perwakilan di Dinas Perindustrian, Perdagangan, Koperasi, Usaha Kecil Menengah dan Tenaga Kerja (PERINDAKOP) Provinsi Papua

Budaya otoritatif, tanggung jawab hierarkis dan disiplin kerja sekaligus mempengaruhi pameran perwakilan di Dinas Perindustrian, Perdagangan, Koperasi, Usaha Kecil Menengah dan Tenaga Kerja (PERINDAKOP) Provinsi Papua.

\section{Saran}

Ide-ide yang dapat diberikan melalui konsekuensi review ini adalah sebagai berikut;

Gagasan Dinas Perindustrian, Perdagangan, Koperasi, Usaha Kecil Menengah, dan Tenaga Kerja (PERINDAKOP) Provinsi Papua, dalam mengembangkan lebih lanjut pelaksanaan pekerja harus memainkan peran penting dalam memperluas masyarakat dan kewajiban untuk bekerja di lingkungan kerja.

Hasil tinjauan ini diharapkan dapat menambah kemajuan pelaksanaan perwakilan dengan memasukkan disiplin yang tinggi di bidangnya masing-masing dalam mencapai tujuan di Dinas Perindustrian, Perdagangan, Koperasi, Usaha Kecil Menengah dan Tenaga Kerja (PERINDAKOP). Provinsi Papua.

Dalam pemeriksaan berikut dapat menambahkan berbagai faktor yang dikecualikan dari tinjauan ini. Faktor yang bisa ditambahkan misalnya inspirasi kerja, gaji, dll.beberapa penelitian Saputra Mutmainnah Herlie, (2010) Kedisplinan merupakan fungsi MSDM yang terpenting dan kunci terwujudnya tujuan karena tanpa disiplin yang baik sulit terwujud tujuan yang maksimal. Kedisplinan adalah keinginan dan kesadaran untuk menaati peraturan- peraturan organisasi dan norma- norma sosial.

Pernyataan di atas dapat didukung oleh penelitian Rizka Afista, (2018). terdapat pengaruh secara parsial variabel disiplin kerja terhadap kinerja pegawai.

Pengaruh Budaya Organisasi, Komitmen Organisasi dan Disiplin Kerja secara Simultan Terhadap Kinerja.

Hipotesis yang terakhir dalam penelitian ini menyatakan bahwa "Budaya Organisasi, Komitmen Organisasi dan Disiplin Kerja secara Simultan Berpengaruh Terhadap Kinerja".

Berdasarkan hasil analisis pada Tabel 4.15 terlihat bahwa nilai $\mathrm{F}$ hitung adalah sebesar 51,258 yang adalah lebih besar dari besarnya $\mathrm{F}$ tabel yang hanya sebesar 2.557 dengan signifikansi 0.000 yang juga < dari nilai $\mathrm{p}$ value 0.005 sehingga $\mathrm{H} 4$ diterima artinya bahwa Budaya Organisasi, Komitmen Organisasi dan Disiplin Kerja secara Simultan Berpengaruh Terhadap Kinerja.

Pernyataan di atas dapat didukung oleh penelitian Rizka Afista, (2018). terdapat pengaruh secara parsial variabel budaya organisasi, disiplin kerja dan komitmen organisasi secara simultan terhadap kinerja pegawai.

\section{DAFTAR PUSTAKA}

Eduard Yohannis Tamaela. 2014. "Analisis Hubungan Kausalitas Budaya Kerja, Kepuasan Kerja Dan Kinerja Karyawan RSUD. Dr. Haullussy Ambon.” Benchmark Jurnal Ekonomi Bisnis \& Akuntansi 3(1):93-106.

Abdul Rahman. 2009. Hubungan Sistem Administrasi Perpajakan Modern dengan Kepatuhan Wajib Pajak. Buku Harian Riset Akuntansi Vol VI Nomor 1. 
terlebih lagi, asosiasi individu cocok. Buku harian moral bisnis. Jil. 41. Nomor 4. and person-organization fit. Journal of business ethics. Vol 41. Nomor 4.

Anwar Prabu Mangkunegara, 2013, Corporate Human Resource Management, Pemuda Rosdakarya, Bandung.

Bangunlah, Wilson. 2012. "Manajemen Sumber Daya Manusia". Jakarta: Erlangga

Christy, Hasna. (2004). Hubungan antara budaya hierarkis dan kewajiban otoritatif pada petugas medis di RS Citarum Wilasa Semarang.

Katalog Kongres.

Danang Sunyoto. 2013. Dasar-dasar Manajemen Pemasaran. Yogyakarta: CAPS.

Danang, Sunyoto. (2013). Metodologi Penelitian Pembukuan. Bandung: PT Refika Aditama Anggota Ikapi.

Darsono dan Siswandoko, Manajemen Sumber Daya Manusia Nusantara

Konseling, 2011.

Denison dan Misra. (2000). Budaya otoritatif dan hierarkis versi. AS: McGraw-Hill. Jakarta:

kecukupan: hipotesis dan beberapa bukti pengamatan mendasar. Sekolah Erlangga

Ghozali, Imam. "Penggunaan Analisis Multivariat Dengan Program SPSS", Badan Penerbit Universitas Diponegoro, Semarang, 2011.

Griffin, Ricky, W. dan Ronald J. Ebert. 2007. Bisnis, versi kedelapan vol. satu. Penafsiran. Jakarta: Erlangga.

Holil, Muhammmad dan Sriyanto, Dampak Disiplin Kerja Terhadap Eksekusi Pekerja terhadap kinerja pegawai (Studi kasus pelayanan pajak BUMN

Ilyas, Yaslis (2002). Eksekusi; hipotesis, evaluasi, dan eksplorasi. Depok: Tengah versi global. New Jersey: Pendidikan Pearson.

Studi Ekonomi Kesehatan FKMUI.

Kerja.

Kasmir, 2011, “Analisis Laporan Mo Raja Grafindo Persada: Jakarta.

Keith, Davis, Jhon W. Newstrom, 1995. Perilaku dalam Organisasi, Edisi Ketujuh, Erlangga, Jakarta. dibuat oleh perwakilan pt para finance. Jakarta: staf ilmu otak. 918. PSSI.

Eksekusi, program. Yogyakarta: Penerbit Andi Offset.

Kreitner, Robert dan Angelo Kinicki, (2001). Perilaku hierarkis; kelima

Luthans, Fred (2008). Perilaku hierarkis. AS: McGraw-Hill.

Luthans, Fred dan Richard Hodgetts, (2003). administrasi global; budaya, Makasar.

Malasari, Nur (2010). Hubungan antara tampilan eksekusi dan penyelesaian

Mannion, Russel. (2008). Memperkirakan dan mengevaluasi budaya otoritatif di

Mathis, Jackson (2009). Aset manusia para eksekutif. Jakarta: Empat Salemba

Mudrajad, Kuncoro, (2003). Metode Penelitian untuk Bisnis dan Ekonomi; Jakarta:

Munandar, Ashar (2001). Psikologi Modern dan Organisasi. Jakarta: Penerbit

NHS (OC1). College of York: Pusat Kesehatan dan Publik dari organisasi bisnis. Perguruan Tinggi Michigan. asosiasi, para eksekutif berkonsentrasi pada program. Perguruan Tinggi Fakultas Ekonomi

Ova Nuracto sofiati, Dampak Disiplin Kerja Terhadap Eksekusi Representatif Studi Kasus di Pusat Pengembangan Perluasan Kerja Lembang, 2015.

Pace, Wayne, dkk., (2005). Korespondensi hierarkis. Bandung: PT Remaja Rosda di Kantor Pelayanan dan Lelang Barang Milik Negara Makassar, program

Pratiwi, Riska (2012). Dampak budaya hierarkis pada eksekusi representatif

Robbins, S.P., dan Hakim, T.A. 2008. Perilaku Berwibawa, Edisi Dua Belas, Jakarta: Salemba Empat.

Robbins, Stephen, dan Mary Coulter. (2010). Papan. Jakarta: Erlangga

Rosado, JL., Lopez, P., Kordas, K., Vargas, GC., Ronquillo, D., Alatorre, J., Stoltzfus, RJ. (2006). Suplementasi Zat Besi atau Seng yang Berpotensi Tidak Mengurangi Konsentrasi Timbal pada Anak-Anak dalam Percobaan Terkendali Secara Acak, Plasebo. J. Nutr. 136 - 2378 - 2383. www.ajcn.org . Dipulihkan 1 April 2012.

Schultz, Duane dan Sydney Ellen, (1994). Penelitian dan pekerjaan otak hari ini; pearson

Manajemen Administrasi. 
Singomedjo, Markum, Manajemen Sumber Daya Manusia Surabaya:SMMAS, 2000.

sofia. (2008). Perilaku Berwibawa, Yogyakarta: Andi Offset.

Peloncat.

Sri Mulyani, Veronica Agustini. (2007). Tipologi dan pendahulu tanggung jawab

Stephen, Robins, (2003). Perilaku berwibawa. Gramedia: PT Indeks.

Steve. (2002). Penelitian otak yang otoritatif. AS Amerika: Perpustakaan

prosedur, dan perilaku. AS: McGraw-Hill

dewan studi, Fakultas Ekonomi dan Bisnis, Universitas Hasanudin:

Sudarmanto, R. Gunawan, 2005. Berbagai Analisis Regresi Linier dengan SPSS. Yogyakarta; Ilmu Ghalia

Bagian pendahuluan berisi latar belakang pentingnya penelitian dilakukan serta kebaruan dari penelitian yang dilakukan dibandingkan dengan penelitian-penelitian sebelumnya. Pada bagian pendahuluan ini juga dicantumkan rumusan singkat tentang pokok bahasan dalam artikel tersebut. Format keseluruhan artikel menggunakan ukuran kertas A4 (29,7 x $21 \mathrm{~cm})$ dan margin atas, bawah, kiri dan kanan $2.54 \mathrm{~cm}$, font Times New Roman, size 11, spasi 1,15 serta rata kanan - kiri. Dimohon ketika mengirimkan artikel dalam format word (doc.) 